\title{
Bridge Structures with Four Arches on Bistrica River in Ocrkavlje
}

\section{Lemja Chabbouh Akšamija, Lejla Šabić}

Faculty of Architecture, Department for Theory and History of Architecture, Sarajevo, Bosnia and Hercegovina

Email address:

lemjaa@af.unsa.ba (L. C. Akšamija), lejlas@af.unsa.ba (L. Šabić)

To cite this article:

Lemja Chabbouh Akšamija, Lejla Šabić. Bridge Structures with Four Arches on Bistrica River in Ocrkavlje. International Journal of Literature and Arts. Vol. 3, No. 3, 2015, pp. 29-33. doi: 10.11648/j.ijla.20150303.12

\begin{abstract}
Bridge in Ocrkavlje is a continuation of research and analytical work and process on documenting bridge structures at the Imperial road in Bosnia or $d z \check{a} a d a$, transversal already in ancient time, established on the territory of the present-day Bosnia and Herzegovina. Among the sixteen processed, there are three bridge structures that are first time treated in this way in term of protection, and whose documentation did not existed. Researching of the last one of the three bridges, the one in Ocrkavlje, confirmed the hypothesis about the belonging of these structures to the "architecture of purposes", as a version of vernacular architecture, the spontaneous dealing with problems at the level of experiential and intuitive, as in a basic postulate of builders or dunđerski work.
\end{abstract}

Keywords: Architectural Heritage, Stone Bridges, Vernacular Architecture, Traditional Bridge Construction

\section{Introduction}

Small stone bridges belong to the category of "unattractive" monuments. Trying to bring order in this area and to find an adequate and sufficiently precise terminology for the term "bridge", which is embodied and situated in a specific time and space and at the same time represents a historical monument, and thereby to avoid any dilemma about term, which is, due the phenomenology of bridge, in the universal language of symbols brought to the absolute, we introduce new term stone bridge structures.

We also wanted to emphasize the specificity of this category of the selected objects, which - as confirmed through examples, have no stylistic features from a certain period, recognized through the masonry, form and decoration. These structures belong to the "architecture of purposes".

All other architectural structures with its forms and decorative elements cannot be categorized as a pure utilitarian objects. There is also the extreme opposite - "vanity architecture", with dominated decoration and plastic, that at some point becomes purpose to itself. Throughout the history of art we are faced with the absurd buildings, such as triumphal arches, for example. This are also arched structures that unlike the stone bridge structures, are spanning nothing and lead nowhere. Their purpose is the idea, and their function is a tribute to a certain person. However, these facilities, which formally have no function, full of decorations and complicated structure, are opposite to our selected stone bridge construction.

Of course, all mentioned does not apply to every new bridge construction. But we have very clearly insisted on the definition of stone bridge structures as small to mid-range stones from the Ottoman-Turkish period, opposed to large spans bridges [1].

By choosing specific locations, Imperial Bosnian road or $d z ̌ a d a$ [2-10], a transversal already in ancient times established on the territory of present-day Bosnia and Herzegovina, this work - as the final phase of research, documentary and analytical part, which included 21 new bridge construction [11], determines and verifies the hypothesis of complete utility and vernacularity of these structures.

Since the work specified the Ottoman-Turkish period as a period of interest, analysis of historic background of the construction brought us to the conclusions about specificity or rather non-specificity of this period, which are related to a selected group of stone bridge structures.

Examined stone bridge structures in structural and stylistic terms do not have any significant characteristics that would classified them in a certain period of construction. This conclusion leads us to the thesis of their "contemporary being", due the technique and absence of style in which they were made. A small number of them have fine deburring stone, 
front walls that are grouted etc. [11]. That caused the unchanged building principles and formal appearance from earliest to the latest examined examples, beetween "Sarah Kašiković" ${ }^{1}$ and "Ćuprija in Stolac"

The technique works, material, as well as the basic form are not significantly changed over time of over 500 years.

Ottoman-Turkish period is characteristic for absence of rules which determine that form dictates construction. The situation is mostly reversed. Power of empirical recognition and problem solving is so strong that it dictates the form. This principle is one of the key characteristics of Ottoman architecture in general. The intuitive and experiential as two important factors permeate every building structure. Bringing together all the characteristic structural elements with the knowledge of materialization, leads at the same time, to the start and to the end. Studied stone bridge structures, in fact, do not contain anything more than these fundamental elements.

\section{Bridge Structure in Ocrkavlje}

Walking down the connecting arm of the Stambol road, which from Rogatice ran through the valley of the river Rakitnica and Prača to Goražde and Foča, one came to Miljevina, or to the village Ocrkavlje, where partially preserved remains of the once imposing stone structures from the Ottoman period are located [12].

Based on precisely painted and preserved aquarelle made by Eduard Loidolta [13], officer of the Austro-Hungarian army and, later, an academic painter, we learn that this bridge construction was settled on five shafts.

We discovered from other documents, that during the Austro-Hungarian presence in this region, upper part of structure, which, due to wear and no protection tended to decline, collapsed, and afterwards was replaced with wooden supplies [14].

Proximity and orientation of the bridge structures towards the tower and houses or odžaci of the complex of family Čengic on Rataji, indicates the existence of the bridge construction at the moment of the construction of this, in those times, extraordinary residential complex with the, most likely, highest tower in the former Bosnia.

Hamdija Kreševljaković notes that this tower was built by brothers Ahmed Pasha and Osman Pasha, who lived in the late seventeenth and early eighteenth centuries [13].

It has been detected, based on the findings in situ, a preserved part of bridge structures of a smaller and a larger port, of indeterminate age, without any distinctive stylistic features.

It is apparent that the bridge structures was built of a slightly more precise dressed stone blocks of different formats, most likely from a material that could be collected on the site, or in its vicinity, with couplings between the stone blocks that

\footnotetext{
${ }^{1}$ Small bridge construction, building for private use at the very beginning of the Austro-Hungarian occupation in Bosnia in 1898.

${ }^{2}$ One-arch bridge construction over the river Bregava in Stolac - one of the oldest structures of this type.
}

are not consistently reduced radially towards the center, but already show less or greater deviations.

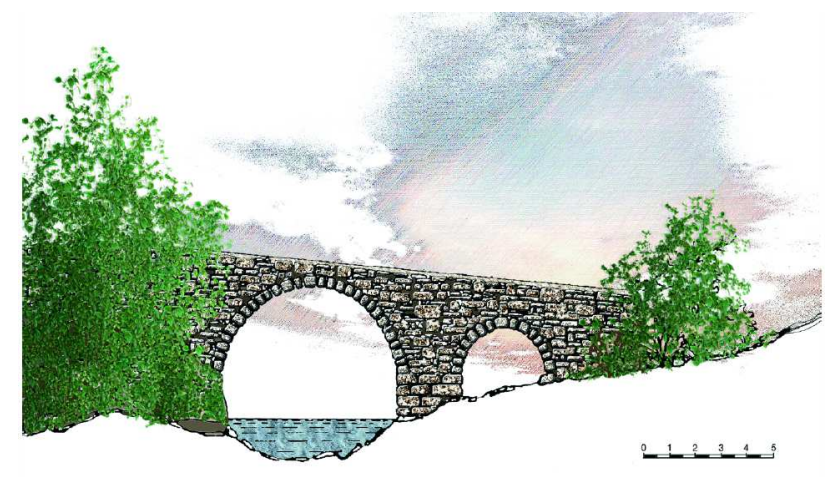

Figure 1. Stone bridge structure on the Bistrica in Ocrkavlje structural characterization of materials and environment - the current state, 1997.

On the spandrel walls is visible the tendency of horizontal layering of stone blocks, but without great precision and consistency - blocks are only approximately following the arched structure and thus create the impression of the existence and of another, enough expressed arc.

The presence of plastics is given on single frontal arches, which are intended about $5 \mathrm{~cm}$ in relation to the surfaces of spandrel walls, both, on the downstream, and on the upstream side of bridge structures.

The slope is constant on the preserved part of the bridge structures, and on the basis of the already mentioned, preserved watercolor of Eduardo Loidolt, we can confidently conclude that it breaks over the vault with the largest radius.

Concerning foundation of bridge structures, it is evident that the builders, with the aim of facilitating the foundation, skillfully used solid big rocks from the riverbed, which are also present on Loidolt's watercolor.

Stated data, along with the knowledge that this was a very wealthy and prominent family, and that this road arm is not stretched beyond the tower and odžkak, give us the right to suppose that the brothers Ahmed-paša and Osman paša at the end of the seventeenth century, and all with the aim of providing construction and normal communication between the tower and odžkak over the river Bistrica with road route for town Foča, hired experienced local builders to build the bridge.

Also, we can point out that they were better local builders who knew how and in which way to overcome almost $40 \mathrm{~m}$ wide riverbed, to use natural rock foundation, and thereby define a certain respectable architectural solution which, with modest stylistic approach, relies on the Ottoman school of bridge construction.

Before collapsing, the bridge construction was placed on three major pillars built of stone blocks, which were founded in the river bed on the existing stone mass. Unfortunately, the builders did not felt the need for forming these pillars in elongated form in the direction of the watercourse with sharper end so that the water mass would crush on then and 
decrease the pressure on the elements, which, most likely, in addition to other vulnerabilities, led to the collapse of the bridge structure.
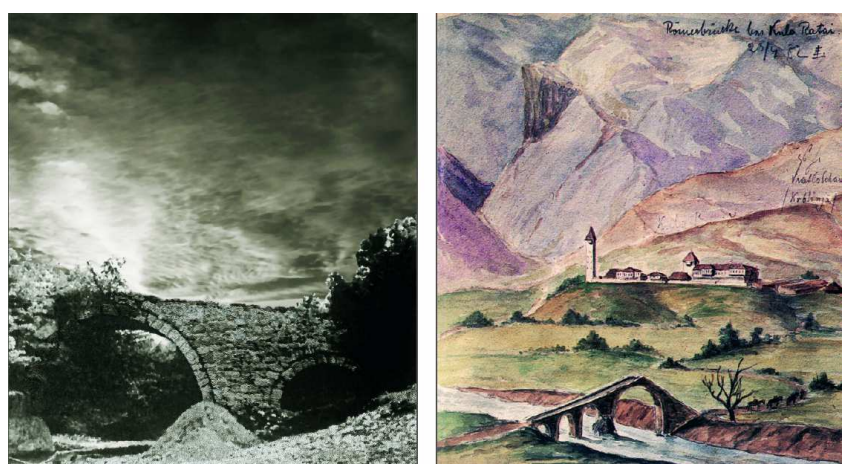

Figure 2. Left: bridge structures in Ocrkavlje - the current situation remaining part of upstream facade. Right: bridge structures in Ocrkavlje with tower and odžak of family Čengić - watercolor: Eduard Loidolt, 1882.

Based on our research, we found out that the width of these columns was about 3.6 meters, and their length about 2.5 meters. With regard to the overall length and width of the bridge structure, such proportions of pillars guaranteed the basic stability of the object at the normal water level, and the already mentioned lack of buttresses were associated with a higher percentage of threat of any torrents that are very frequent in this region were.

The columns, depending on the size of the radius and compositional arrangement, have rounded endings, which are leaning on the frontal walls, in approximately, three-quarters of the height of the structure above the normal water level.

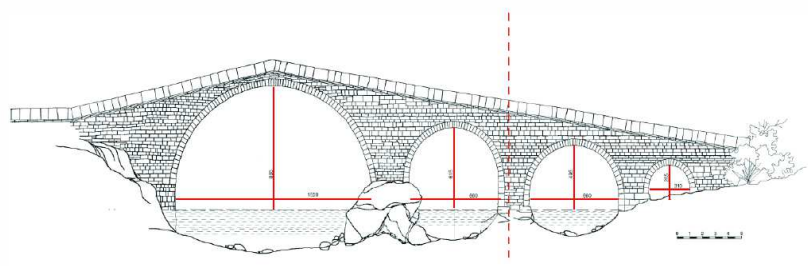

Figure 3. Bridge structures with four arches on Bistrica River in Ocrkavlje upstream facade - conceptual reconstruction, 2000.

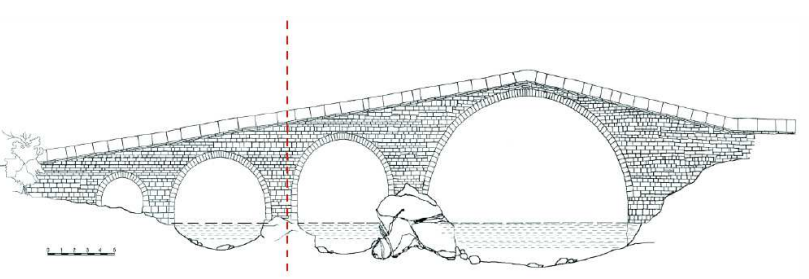

Figure 4. Bridge structures with four arches on Bistrica River in Ocrkavlje downstream facade - conceptual reconstruction, 2000.

The transition from the vertical in rounded part of the pier is emphasized by the molded cornice. We cannot escape the impression of another lack of construction - better insurance of supports of bridge structures on the right, deeper and more vertical coast in the form of protective retaining walls built in stone blocks, upstream and downstream - could have prevented the demolition of coastal land mass and provide construction of access ramps.

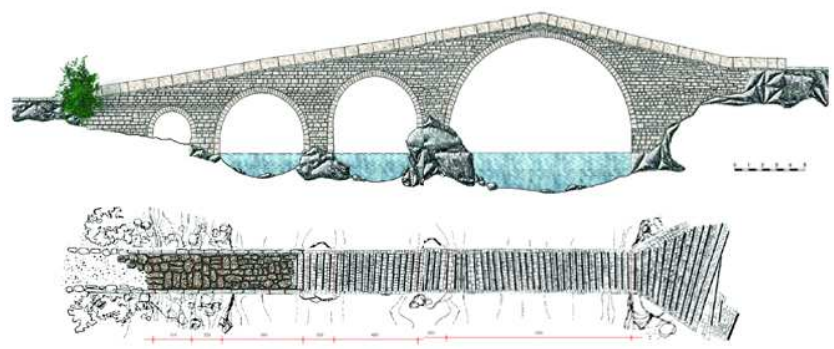

Figure 5. Downstream facade and ground plan - Conceptual reconstruction, author's reconstruction, with elements of structural characterization of materials and environment, based on watercolors of Eduard Loidolt.

On the described pillars rested three ports of unequal width, in range from 6.60 to 15.20 meters. Beside the left, shallow bank is the fourth arch, under which, in the terms of normal water level, water mass did not flowed. A diameter of this arc is less than half of the minimum diameter above water. In shape, these arches are not classic Ottoman pointed arches, but, for they relatively small eccentricity of curvature center, closer to the semi-circular shape, which is also one of the characteristics of bridge structures in the Ottoman period.

The total length of bridge structures was about 55 meters and consisted, starting from the left to the right bank, of the following structural sizes: width of retaining ramp around 8 meters, first opening 3.10 meters, first pillar 2.50 meters, second opening 6,60 meters, second pillar 2.50 meters, third opening 6.60 meters, third pillar of 2.50 meters, fourth opening 15,20 meters and the width of the second retaining ramp around 8 meters. Height of bridge structures at its highest point, at the normal water level, above the middle of the fourth opening was 10,85metara, where the roadway slightly decline towards the left bank and expressive and with shorter fall towards the right bank.

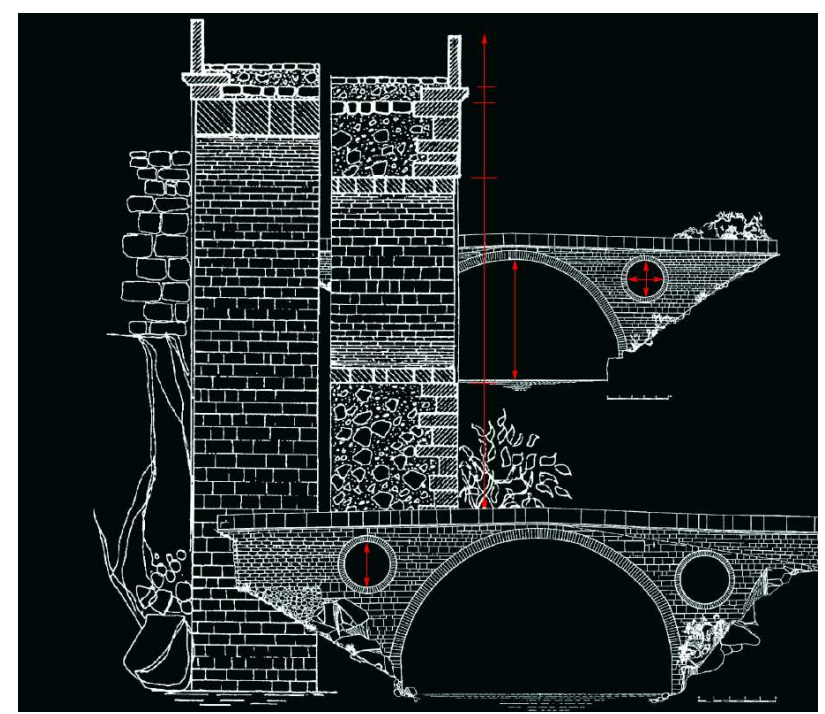

Figure 6. Specific cross section of a bridge structures from the Ottoman period - Kozja Ćuprija, near Sarajevo, whose arch dimensions corresponds to the largest reconstructed arch of the bridge in Ocrkavlje. 
Width of bridge structures was $4.5 \mathrm{yds}$, or 3.60 meters, of which is twice of 0,20 meters width of fence walls - korkaluk. The thickness of the arch structure, at the widest range, was about 0.50 meters. The slop of structures on the facades was delineated with simple molding of cornice, cca 0.10 meters height, which bearded the korkaluk.

Relatively proper arrangement of columns and treatment of wing walls on the sides towards the edges of the river bed, led to specific treatment of sizes and heights of openings, resulting in special facade appearance.

Pronounced fourth hole, a round-arched like other openings, differs from the third and second in 8.60 meters, which is the approximate value of the height of the fourth opening. The first opening is nearly $50 \%$ lower than the second and third. When the opening height is concerned, we can say that it is in proportion, with each opening, depending on its width.

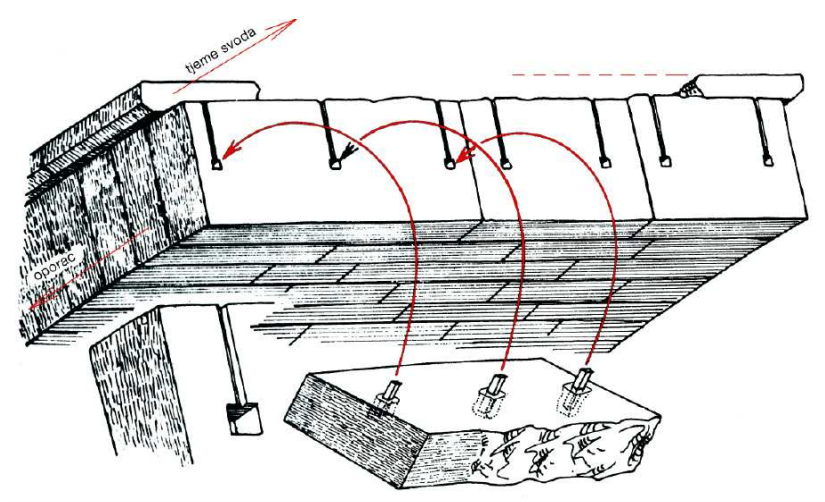

Figure 7. Detail of masonry construction of most arches from the Ottoman period

Finally, we must note the exceptional architectural restraint in proportion of structural elements in circumstances which were defined with character of the location and the value in use.

Such a facility could have been realized due to experienced builders with, good analytical and constructive approach to the existing facilities of this and earlier periods in relation to the client's requirements, financial conditionality and available material.

\section{Conclusion}

Analysis of the bridge in Ocrkavlje represents the final part of the analysis process of 21 stone bridge structures of which we 16 of them, considered to be the most interesting, have located, compared and analyzed through their original and present-day condition.

Parsing therefore stone bridge structures into constituent elements, brought us to conclusion that they do not possess any of the detail that is not in a function of the structure. This conclusion, through a review of history of architecture, and comparison of the stone bridge structures with the other architectural objects, lead us to certainty that only residential buildings in the early hours of the occurrence of any civilization can be classified in the same category, which we called "architecture of purposes".

Presented examples confirm the hypothesis of the contemporarity of objects without certain stylistic affiliation, which were built with hands and knowledge of domestic builders, in a large span of time, having more similarities than differences.

One of the main reasons of durability of the stone bridge structures with vaults is his inviolable stability. Specifically, the cross section of bridge confirms the movement of longitudinal forces in area of brunt, and the fact how very difficult the control moments can be lost.

Each of these elements is primarily in function of the structure or vice versa, the structure is composed of the basic elements and no additional segments.

The need of builders to see every task as very different, to exam itself, conceive and form it within the existing spatial conditions and achieve a step forward compared to contemporaries and predecessors, is considered as basic approach of builder in Ottoman period.

The whole process of creating is up to the seventeenth century based on experiential and intuitive method of action, which is, as empirical attitude, inherited from the Roman bridge construction.

\section{References}

[1] Ü. Özis, Y. Özdemir, A. Atalay, „Turkish masonry bridges of Sinan's time, Bridging large spans from antiquity to the present", Proceedings of the IASS-MSU International Symposium, Istanbul, 2000., pp. 1-10.

[2] C. Bricker, G. Roe Crone, „Landmarks of mapmaking - an illustrated survey of maps and mapmakers“, Oxford, 1976.

[3] F.E. Brown, „Roman Architecture (The great ages of World architecture series)“, New York, 1979.

[4] A. Kiss, „A contribution toresearch on the historical geography of the first extant "reambulation" sketch from the Carpathian Basin“, Zbornik Odsjeka za povijesne znanosti Zavoda za povijesne i društvene znanosti HAZU, vol. 19, Zagreb, 2001.

[5] M. Kozličić, „Kartografski spomenici hrvatskog Jadrana izbor karata, planova i veduta do kraja 17. stoljeća“, Zagreb, 1995.

[6] A. Pandžić, "Stare karte i atlasi Povijesnog muzeja Hrvatske", Zagreb, 1987.

[7] E. Pašalić, „Antička naselja i komunikacije u Bosni i Hercegovini“", Sarajevo, 1960.

[8] C. Polto, „La Sicilia di Tiburzio Spannocchi - una cartografia per la conoscenza e il dominio del territotio nel secolo XVI“", Firenze, 2001.

[9] C. Tadgell, ,Imperial space - Rome, Constantinople and the early church", New York, 1998.

[10] J. Zagoda, „Ceste i mostovi“, Zagreb, 1975.

[11] L.Chabbouh-Akšamija, „Architecture of purpose“, unpublished. 
[12] H. E. Ayverdi, „Osmanli mimari eserleri - Yugoslavya“, II - 3. kitap, Istanbul, 2000, ev. no. 1792., pp. 270.

[13] I. Krzović, „Eduard Loidolt, akvareli iz Bosne i Hercegovine 1880-1882.," Sarajevo, 1999., pp. 9-33.
[14] Dž. Čelić, M. Mujezinović M., „Stari mostovi u Bosni i Hercegovini““, Sarajevo, 1998., pp. 196. 